\title{
Revolving Door Paradox of Textile Industry in Ethiopia: A Quantitative analyses of High Labor Turnover
}

\author{
Lelisse B. Tadesse ${ }^{1}$ \\ ${ }^{1}$ Commercial Bank of Ethiopia
}

\begin{abstract}
Background: The study aims to assess the determinants of employees' turnover in the Ethiopian textile industry. Methodology: To assess the determinants of the problem, a sample of four companies were included in the study from four different Regional States (Tigray, Amhara, Oromia, and SNNPR). The principal sources of the data were employees, key informants, and employers in the textile manufacturing enterprise. A structured questionnaire with CSpro software was used to gather the information. A Probit Econometric Regression analysis was applied to analyze the data and draw a conclusion. Findings: The findings of the study revealed that workers' dissatisfaction with their job, work environment, and salary dissatisfaction have a significant and positive relationship to their intention to leave the companies. However, as expected, supervisors' good relationship with the workers has a significant effect to reduce the probability of the worker's intention to leave the company. Compared to males, female workers are more likely to intend to leave. This could be associated with inconvenient work schedule and works stress. The result of the analysis also shows that the larger the family sizes, the less likely are the workers intend to leave their company which could be associated to fear of risk against the family livelihood.
\end{abstract}

Key words: Employee turnover, intention to leave, Textile and Garment industry

\section{Introduction}

According to Martin (2005), when employees leave a company, the employer incurs a considerable amount of direct and indirect expense. The costs of employees' turnover normally include advertising expenses, headhunting fees, resource management expenses, loss of time and efficiency, work imbalance, and training and development expenses for new joiners (Harrie; 2002). According to Oregon (2004), most companies find that employee turnover can be reduced when issues affecting employee morale are addressed. Ethiopia being with abundant labor supply, high turnover is repeatedly reported by many manufacturing companies. It is indicated that nearly two-thirds of new production workers who join the garment and textile factories quit after six months (International-Labor-Organization; 2019).
This is a serious paradox to the government as given that a considerable number of the population is jobless and looking for employment; that is, while unemployment is alarmingly increasing, there is a massive turnover in manufacturing companies located all over the country. The publication of the Industrial Strategy Paper (2002) of the Ethiopian government revealed that the textile and garment industry in Ethiopia has been considered as one of the priority industries that are labor-intensive and export-oriented, as explicitly documented in Plan for Accelerated and Sustained Development to End Poverty (PASDEP), Growth and Transformation Plan one and two (GTP-I and GTP-II) and National Employment Policy (FDRE; 2016).

The paradox is that, while there happens to be a massive 
unemployment problem of educated youth in the economy, the manufacturing enterprises (both FDI and Local investors) complain about severe labor shortage and high rate of turnover for both skilled and unskilled labor. The Labor Market Report (2019) by fitch solutions group limited also states that manufacturing businesses are neither adequately pooling enough labor force nor sustainably retaining those employed despite the rising unemployment problems in the country. The research questions are, therefore, what are the most important determinants of employees' turnover in the textile industry? What should be the mitigating measures to reduce the labor turnover?

\section{Literature Review}

\subsection{Theoretical Literature}

Labor turnover is the ratio of the number of workers that have to be replaced that can be calculated in a month or a year (Ferreira and Almeida; 2015). Herzberg developed the two-factor theory by interviewing 203 accountants and engineers in the Pittsburgh area (Matei and Abrudan; 2016; Alase and Akinbo; 2021). While developing the theory, Herzberg stated that if working conditions are poor, but an individual chooses to have a job it could be due to company policy, interpersonal relations, benefits, job security, salary, and supervision. According to Herzberg et al. (1959), extrinsic factors are those factors that do not always lead to greater job satisfaction but rather are expected factors attributing to the everyday nature of the job.

On the other hand, intrinsic motivators are the forces that push an individual to make a choice in one direction or another and are significantly influenced by how an individual perceives a situation (Matei and Abrudan; 2016) it includes achievement, recognition, advancement, the possibility of growth, the enriching or rewarding aspects of the job itself, and the ultimate responsibility proffered by the job or position (Alshmeri and Maude; 2017; Noko and Nwuzor; 2021). Vroom developed the expectancy theory in 1964 based on performance expectation, recognition of performance, and value of recognition (Hayibor and Collins; 2016). For example, if managers want to keep expert employees, the focus should be identifying methods to allow employees to find intrinsic (motivational) value within their positions (Vroom and Deci; 1983).

Ghoddousi et al. (2014) also conducted a study that utilized the expectancy theory consisting of 194 employees and found that intrinsic factors were more effective than extrinsic factors in the construction industry. Maslow's theory suggested humans have hierarchy of needs that must be met in order of lowest to highest (Maslow, 1943 see (Noko and Nwuzor; 2021)). For example, individuals will not become concerned about their safety until after the primary physiological needs such as food and water are met. Furthermore, Maslow found that if employees do not feel safe in the working environment promotion and awards will not be their concern. The theories show that both internal and external factors must be considered in crafting an employee retention strategy.

\subsection{Empirical Literature}

According to ECarsten and Spector (1987), job satisfaction is a factor that is critical to consider when predicting employee's intention to leave. It explains that people who are unhappy with their jobs are likely to quit in order to find a better alternative elsewhere. However, studies have produced mixed results. Some researchers have reported non-significant relationships between satisfaction and turnover intentions (e.g. (Harris and Cameron; 2005; Kacmar et al.; 1999). Supporting the latter findings, Erdogan et al. (2012) estimated the population correlation to be low. In contrast, according to De-Cuyper et al. (2009) and Rode et al. (2007), greater job satisfaction is associated with low intention to leave. DeConinck (2009); Gerstner and Day (1997); Graen and Uhl-Bien (1995) explained the quality of relationship between a supervisor and subordinate workers. They explained how this affects the employee's behaviors and attitudes including intention to leave. Previous studies have shown that this variable affects not only intentions to leave (Gerstner and Day; 1997), but also numerous other factors including performance (Liden et al.; 2006), organizational commitment (Cohen-Charash and Spector; 2001), and citizenship behaviors (Ilies et al.; 2007).

On the other hand, other studies show that this relationship may not be so straightforward. For example, Morrow et al. (2005) found a non-linear relationship between supervisor relation and turnover such that turnover was lowest when the relationship was moderate. In addition, according to the studies made byGraen et al. (1982) and Vecchio (1985) the relationship between supervisor relation and actual turnover has been quite equivocal. Based on the norm of reciprocity (Eisenberger et al.; 1986), one would expect that employees perceiving high levels of appreciation and resources from their organizations would be less inclined to leave their jobs.

Most of the empirical research to date supports this prediction, with scholars reporting a strong negative relationship between value of employees' contribution and turnover intentions (e.g. (Allen et al.; 2003; Chew and Wong; 2008). Others, however, have reported moderate (Karatepe; 2012) or even non-significant relationships for certain types of employees, e.g., law firm partners. However, workplace stress has ambiguous results. For example, work-family conflict, a source of workplace stress that occurs when work and home responsibilities collide, resulted in greater time-lagged turnover intentions for permanent workers, but not for temporary workers (Mauno et al.; 2015).

Organizational commitment has emerged as one of the strongest attitudinal dimensions for the human resources management literature (Hom and Griffeth; 1995). Generally, the higher is the organization commitment; the lower is workers' intention to leave. This relationship has been tested in several studies and is generally concluded to be a strong predictor of employee turnover (Kwon et al.; 2010; Gamble and Huang; 2008; Cole and Bruch; 2006; Cohen; 2003).

\subsection{Economic Role of Textile Industry in Ethiopia}

According to International-Labor-Organization (2019), before the formal operation of textile and garment industry in 1930s, there is a long history of textile and garment industry in the traditional form of spinning, weaving and handloom. The high levels of labor intensity and its potential link to the agricultural sector has made the sector a key policy focus area for job creation and exports throughout the 20th and the 21st centuries. The textile and garment industry remained a key industry designated for promotion in the formulation and implementation of industrial policies and development plans with different styles and vigor by various governments.

International-Labor-Organization (2019), further noted that in the 1990s, the sector employed nearly a third of all workers in the manufacturing industry. While this share 
has steadily declined in recent years, the industry still employs close to $17 \%$ of the entire workforce engaged in the formal manufacturing sector. Indeed, the industry is highly labor-intensive; employing 555 workers on average, of which $76 \%$ are female workers. Yet, the pace of job creation in the industry still remains far lower than targets set by the government. For examination, it achieved only $50 \%$ of the job creation targets set in the Growth and Transformation Plan (GTPI) document.

The gross value production of textile and garment industries was only 700 million and 55.7 million birrs respectively in 2001. This figure jumped to 5.8 billion for textile and 0.97 billion birrs for garments in 2014, which is equivalent to a compounded annual average growth rate of $17.7 \%$ and $23.8 \%$, respectively (International-Labor-Organization; 2019). According to Staritz et al (2017), the export from the industry increased to 62 million USD in 2010/11 and further to about 109 million USD in 2017/18. It is noted that in recent years, export from the parks has increased, and the Government of Ethiopia hopes to bring in textile exports worth $\$ 30$ billion by 2025 . As noted in (International-Labor-Organization; 2019), taking all scales of the textile and garment industries at the country level, the sector has created close to half a million jobs in (CentralStatistical-Agency; 2014) and most of the jobs are created in the textile sector (about $86 \%$ ). Interestingly, most jobs created are concerned in rural area (about $58 \%$ ).

\section{Methodology}

\subsection{Sources and Method of Data Collection}

Sample of four (4) companies were included which are distributed across the major industrial towns in Ethiopia. The principal source of the data for the study were the employees, key informants, and employers in the textile manufacturing companies indicated. Because the population was unknown, Cochran (1963) formula was applied for determining the sample size, which is popularly used for such purpose when it is difficult to determine the sample frame. Accordingly, a total sample size of 142 individual workers was randomly selected for interview. The sample size is roughly equally distributed (purposive sampling) across the selected companies. Yet, it would not affect the quality and representativeness of the data given the large population and sample size in each of the companies. The formula employed as indicated in Cochran (1963) for determining the sample size is:

$$
n=\operatorname{deff} \frac{\left(Z_{\alpha / 2}\right) 2 * P(1-P)}{\epsilon^{2}}
$$

Where

$\mathrm{n}=$ the required sample size. $Z_{\alpha / 2}=\alpha / 2$ standard normal distribution score, $90 \%$ value $(1.65)$ is considered. $\mathrm{P}$ equal the estimated proportion of an attribute that is present in the population (taken as 0.5 (default value)). And $\epsilon=$ margin of error $6.9 \%$ is used for this purpose. Deff. equal anticipated design effect, 1 is used for this purpose; and considering $5 \%$ for nonresponses.

To meet the objectives of the study, both primary and secondary data were collected. The secondary data was collected from different institutions like, Central Statistics Agency (CSA), Ethiopian Ministry of Labor and Social Affairs (MoLSA), International Labor Organization (ILO) and GIZ. Review of literature and browsing through the internet were additional sources of information.
Table 1. Sampled Respondents, Region and Location

\begin{tabular}{l|l|l|l}
\hline Region & Location & Name of Companies & Sample Size \\
\hline 1. Oromia & Bishoftu & Canoria Africa Textile PLC & 36 \\
2. SNNPR & Hawasa & JP Textile Ethiopia Plc & 35 \\
3. Amhara & Kombolca & Ammar PolicyPropile PLC & 35 \\
4. Tigray & Axum & AlmendaTextile & 36 \\
Total & & & 142 \\
\hline
\end{tabular}

Information from the managers of the companies and key informants was collected using checklists (through email) as well as through telephone conversations. The information from the employers (managers) was taken to represent the demand side of the labor market, which were basically qualitative and narrative explanations. Most importantly, majority of the data were collected from the workers (employees of the companies) representing the supply side of the labor market. The workers were a mix of laborers and experts. A standard questionnaire was prepared to collect the primary data. The data collection was made through telephone and email because of the pandemic COVID-19, three data collectors were organized under one supervisor. Technical training regarding the concepts, definitions, and methods of collecting data was provided to the data collectors.

The training program involved sessions for explaining the purposes of the study, explanations of the different sections of the questionnaires, and the manner of capturing responses via Computer Assisted Personal Interviews (CAPI) using "tablets". The completed responses were properly captured using the CSPro software installed on the tablets. The collection of the data took 15 days, and sampled were collected based on information in Table 1

\subsection{Econometrics Model Specification}

Employees' intention to leave is an important concept that is used as a proxy for real turnover and an important predictor of employee devotion to a company (Menon et al.; 2018; VanBreukelen et al.; 2004). A binary Probit model was used for the econometric analysis to identify the major determinants of employees' turnover (proxied by intention to leave) in Textile industries to explain the behavior of a dichotomous dependent variable. Although there is no compelling reason to choose logit over Probit in practice many researchers choose the logit model because of its comparative mathematical simplicity and the logistic model has been used extensively in analyzing growth phenomena, such as population, GNP, money supply (Gujarati; 2004). The probit model is described by the binary outcome $y_{i}$.

Where, $y_{i}=1$ if an employee intends to leave; $y_{i}=0$ if an employee intends to stay. The linear model is given by;

$$
y_{i}=\beta_{1}+\beta_{2} x_{i}+\varepsilon_{i}=x_{i} \beta+\varepsilon_{i}
$$

Where $x_{i}=\left(x_{i} 1, x_{i} 2\right), \varepsilon_{i} \sim N\left(0, \sigma^{2}\right)$

The probability that an employee intends to stay is expressed as;

$$
p\left[\varepsilon_{i}=x_{i}^{\prime} \beta \mid x_{i}\right]=p\left[y_{i}=0 \mid x_{i}\right]=1-x_{i}^{\prime} \beta .
$$

The probability that an employee intends to leave is expressed as 
Table 2. Summary of hypothesized variables

\begin{tabular}{|c|c|c|c|}
\hline Variables & Description & Value /Categories & Expected Sign \\
\hline 1. Intention to leave & $\begin{array}{l}\text { Intention to leave is the dependent variable taken } \\
\text { as a proxy of turnover }\end{array}$ & $\begin{array}{l}0=\text { intention to stay } 1=\text { intention } \\
\text { to leave }\end{array}$ & \\
\hline 2. Gender & refers to the sex of the respondents & $0=$ male $1=$ Female & Positive \\
\hline 3. Age & It is the age of the respondents & Continuous variable & Negative \\
\hline 4. Marital Status & $\begin{array}{l}\text { It refers to whether the respondents are married } \\
\text { or single }\end{array}$ & $0=$ single $1=$ married & Negative \\
\hline 5. Migration & $\begin{array}{l}\text { refers to from where the employees are coming } \\
\text { for the Job }\end{array}$ & $\begin{array}{l}0=\text { Just from around the company } \\
1=\text { far from other regions/zones } \\
2=\text { from Addis Ababa }\end{array}$ & Negative \\
\hline 6. Family size & The size of family of the respondents & Continuous variable & Negative \\
\hline 7. Supervisor relation & $\begin{array}{l}\text { It is the relationship of the supervi- } \\
\text { sors(managers) with the workers }\end{array}$ & $0=$ Bad 1=Good & Negative \\
\hline 8. Job Satisfaction & $\begin{array}{l}\text { It is the satisfaction that employees have while } \\
\text { doing the job }\end{array}$ & $0=$ satisfied $1=$ dissatisfied & positive \\
\hline 9. Salary satisfaction & It is the satisfaction from the salary received & $\begin{array}{l}\text { 0=Neutral; } 1=\text { satisfied; } 2=\text { dissat }- \\
\text { isfied }\end{array}$ & Positive \\
\hline 10. Work environment satisfaction & $\begin{array}{l}\text { It is the work stress, safety and rules and regula- } \\
\text { tions of the company }\end{array}$ & $\begin{array}{l}0=\text { Neutral; } 1=\text { satisfied; } 2=\text { dissat }- \\
\text { isfied }\end{array}$ & positive \\
\hline
\end{tabular}

Table 3. Salary Satisfaction Vis-a-Vis the Intention Leave and Working Environment satisfaction Vis-a Vis Intention to Leave

\begin{tabular}{|c|c|c|c|c|c|c|c|c|c|}
\hline Salary Satisfaction & & & Intention to Leave & & Working Environment Satisfaction & & & Intention to Leave & \\
\hline & No & Yes & Total & $\%$ & & No & Yes & Total & $\%$ \\
\hline Satisfied/neutral & 13 & 42 & 55 & $38.7 \%$ & Satisfied/neutral & 20 & 75 & 95 & 67 \\
\hline Dissatisfied & 10 & 77 & 87 & $61.3 \%$ & Dissatisfied & 3 & 44 & 47 & 33 \\
\hline Total & 23 & 119 & 142 & & Total & 23 & 119 & 142 & \\
\hline
\end{tabular}

$$
p\left[\varepsilon_{i}=1-x_{i}^{\prime} \beta \mid x_{i}\right]=p\left[y_{i}=1 \mid x_{i}\right]=x_{i}^{\prime} \beta .
$$

In general, we have $p\left[y_{i}=1 \mid x_{i}\right]=G\left(x_{i}, \beta\right) \ldots$

Equation (5) indicates that the probability of having $y_{i}=1$ depends on the vector $x_{i}$ containing individual characteristics. Clearly, the function $G($.$) in (5) should take on values in$ the interval $[0,1]$ only. Usually, one restricts attention to functions of the form; $G\left(x_{i}, \beta\right)=F\left(x_{i} \beta\right)$. As $F($.) also has to be between 0 and 1 , it seems natural to choose $F$ to be some distribution function. Common choices are the standard normal distribution function, the data coding is as presented in Table 2

\section{Result and Discussion}

\subsection{Results of Descriptive Analyses}

Out of the total respondents (142), female accounts for $18 \%$ and male accounts for $82 \%$. Most of the respondents are between the 25-28 years with an average of 26 years. Descriptively, both male $(83 \%)$ and female ( $89 \%)$ have reported their intention to leave their company. The total respondents' majority of them $(74.5 \%)$ of them completed first degree. The remaining $15.49 \%$ completed secondary school, $4.93 \%$ completed TVET, $3.52 \%$ completed diploma.

The mean Net salary of the respondents is 3,892.7 birr per person per month. The net pay ranges widely from as low as 700 birr to as high as 9,000 birr per month and indicated with a high standard of deviation Birr 1,951 . This is roughly equivalent to USD \$20 - USD \$257 (calculated $1 \$=35$ birr) as per the survey. This is indicating that the minimum salary is less than one dollar per day which is very low. The respondents responses are coded and presented in Table 3
Of particular interest in this regard is that machine operators are more inclined to leave their job due to the difficult nature of their work. Interestingly, 79\% $(=75 / 95)$ of those reported satisfied and or neutral with the working condition have the intension to leave and $94 \%(=44 / 47)$ of those dissatisfied have the intension to leave.

The information gathered through Key informant interview (KII) indicated that high sound pollution, fatigue and dust are among the major challenges that the workers in the weaving, long chain beamer (LCM) and spinning department face respectively and these in turn adversely affects the lung, kidney and sight of the workers. Furthermore, chemicals used in the dyeing department have also damaging effect on their health conditions and could even cause cancer particularly in a situation where they do not use the recommended personal protective equipment (PPE).

\subsection{Result of Econometric Analysis}

In this section, econometric analysis of the variables under investigation was undertaken. A Probit maximum Likelihood model was applied to the proposed variables. The model passed through important tests like omitted variable test, goodness-of-fit and multicollinearity to evaluate the overall significance and explanatory power of the model.

The Hosmer-Lemeshow Goodness of Fit test was applied to Probit model. It describes how the model fits a set of observations (the discrepancy between observed values and the values expected under the model in question). If the fit is good (null hypothesis is true), the observed and (model based) expected counts will be close to each other and their differences will be small. The actual test statistic is a sum of (observed-expected)/expected ${ }^{2}$ and is distributed chi square under the null hypothesis. The test $(p=0.7773)$ suggests no statistically significant departure from a good fit. The null hypothesis of "good fit" is NOT rejected (Gujarati; 2004).

Multicollinearity was tested by using a correlation matrix 
Correlation matrix of coefficients of probit model

\begin{tabular}{|c|c|c|c|c|c|c|c|c|c|c|c|}
\hline$e(V)$ & $\begin{array}{l}\text { codein-d } \\
\text { super _n }\end{array}$ & jobdisat & rorkdi-t & salard.t & Icode. 1 & Icode -2 & AGB & familive & gender $v y$ & marita-m & cons \\
\hline codeintend & & & & & & & & & & & \\
\hline super_rela $n$ & 1.0000 & & & & & & & & & & \\
\hline jobdisat & -0.4080 & 1.0000 & & & & & & & & & \\
\hline workdisat & -0.2562 & 0.3266 & 1.0000 & & & & & & & & \\
\hline salardisat & -0.0832 & 0.0949 & -0.1201 & 1.0000 & & & & & & & \\
\hline IcodeVigr $* 1$ & 0.0020 & 0.1680 & -0.0414 & $0.112 B$ & 1.0000 & & & & & & \\
\hline IcodeVigr $* 2$ & -0.0062 & 0.0783 & -0.0533 & 0.0274 & 0.7538 & 1.0000 & & & & & \\
\hline$A G B$ & -0.0924 & 0.1791 & 0.0481 & 0.1020 & 0.0696 & 0.1468 & 1.0000 & & & & \\
\hline familiysize & -0.0118 & -0.0174 & 0.1274 & -0.0252 & -0.2378 & 0.0828 & 0.2613 & 1.0000 & & & \\
\hline gende rduminy & -0.0868 & 0.2960 & 0.0115 & 0.0928 & 0.0420 & 0.0703 & 0.1835 & -0.1210 & 1.0000 & & \\
\hline maritaldum & 0.0165 & 0.2114 & -0.1514 & -0.0474 & 0.0174 & -0.0184 & -0.1176 & -0.0975 & 0.1997 & 1.0000 & \\
\hline cons & 0.0385 & -0.3076 & -0.0842 & -0.1794 & -0.3010 & -0.4165 & -0.9315 & -0.3249 & -0.2399 & 0.0467 & 1.0000 \\
\hline
\end{tabular}

Figure 1. Multicollinearity Test

Table 4. Robust Probit Maximum Likelihood Estimation

\begin{tabular}{|c|c|c|c|c|c|c|c|}
\hline Intension to Leave & Coef. & St. Err. (Robust) & t-value & $\mathrm{p}$-value & $95 \%$ Conf & Interval & Sig. \\
\hline super-relation & -0.606 & 0.331 & -1.83 & 0.067 & -1.254 & 0.043 & $*$ \\
\hline work-disat & 0.735 & 0.402 & 1.83 & 0.068 & -0.053 & 1.523 & $*$ \\
\hline Job-disat & 0.968 & 0.325 & 2.98 & 0.003 & 0.331 & 1.605 & $* * *$ \\
\hline Salar-disat & 0.507 & 0.294 & 1.72 & 0.085 & -0.070 & 1.084 & $*$ \\
\hline Migration1 & 0.631 & 0.542 & 1.16 & 0.244 & -0.431 & 1.693 & \\
\hline Migration2 & 0.066 & 0.457 & 0.14 & 0.886 & -0.830 & 0.962 & \\
\hline Gender & 0.765 & 0.363 & 2.11 & 0.035 & 0.053 & 1.477 & $* *$ \\
\hline Marital Status & 0.343 & 0.349 & 0.98 & 0.325 & -0.340 & 1.026 & \\
\hline AGE & 0.055 & 0.054 & 1.02 & 0.306 & -0.050 & 0.160 & \\
\hline Family size & -0.164 & 0.073 & -2.23 & 0.026 & -0.308 & -0.020 & $* *$ \\
\hline Constant & -1.118 & 1.610 & -0.69 & 0.487 & -4.273 & 2.038 & \\
\hline Pseudo r-squared & 0.190 & Number of obs & 142.000 & Chi-square & 29.673 & Prob > chi2 & 0.001 \\
\hline
\end{tabular}

$* * * \mathrm{p}<0.01, * * \mathrm{p}<0.05, * \mathrm{p}<0.1$. I Source: Computed from Survey Data

Table 5. Robust Probit Maximum Likelihood Estimation

\begin{tabular}{llllllll}
\hline Variable & $\mathrm{dy} / \mathrm{dx}$ & Std.Err. & $\mathrm{Z}$ & $\mathrm{P}>\mathrm{z}$ & {[} & $95 \%$ & C.I. \\
\hline Super-rln & -0.107 & 0.054 & -2.000 & 0.046 & -0.213 & -0.002 & 0.599 \\
Job-disat & 0.229 & 0.097 & 2.350 & 0.019 & 0.038 & 0.420 & 0.704 \\
Work-diss & 0.121 & 0.054 & 2.220 & 0.027 & 0.014 & 0.227 & 0.331 \\
Salary-diss & 0.103 & 0.063 & 1.650 & 0.100 & -0.020 & 0.226 & 0.613 \\
Migration1 & 0.098 & 0.079 & 1.240 & 0.214 & -0.057 & 0.253 & 0.246 \\
Migration2 & 0.013 & 0.104 & 0.120 & 0.903 & -0.191 & 0.216 & 0.676 \\
Age & 0.010 & 0.011 & 0.970 & 0.332 & -0.011 & 0.031 & 26.183 \\
Family size & -0.031 & 0.015 & -2.000 & 0.045 & -0.061 & -0.001 & 2.254 \\
Gender & 0.107 & 0.046 & 2.320 & 0.020 & 0.017 & 0.196 & 0.176 \\
Marital & 0.057 & 0.060 & 0.940 & 0.345 & -0.061 & 0.176 & 0.197 \\
Pseudo r-squared & 0.190 & Number of obs & 142.000 & Chi-square & 23.925 & Prob chi2 & 0.008 \\
\hline
\end{tabular}

*** $\mathrm{p}<0.01, * * \mathrm{p}<0.05, * \mathrm{p}<0.1$. I Source: Computed from Survey Data 
the absolute value is $>0.8$ among two or more predictors it indicates the presence of multicollinearity. In our case, the result of test indicates that there is no existence of multicollinearity as revealed in Figure 1. According to Agresti (2002), probit regression model are neither normally distributed nor have constant variance (homoscedastic). Therefore Gujarati (2004) recommended robust regression to control for heteroskedasticity in binary outcome models (see Table 4 . In line with the model specification in the Methodology section, the functional Probit maximum likelihood Model is built on a latent variable $(*)$ with the following formulation:

Intention to Leave $X_{i} \beta+\varepsilon_{i}$

Where, $\beta$ equals vector of coefficients and $X_{i}$ equals vector of independent variables. If Intention to leave greater than 0 , we have intention to leave equals 1 and if Intention to leave less than or equal to 0 , we have Intention to leave equals 0 . Therefore, the probit model was defined as follows:

$$
\begin{array}{r}
\text { Prob(Intention = } 1)=\beta_{0}+\beta_{1} \text { Superv }_{r} \text { elation }+\beta_{2} \text { Job }_{d} \text { isat } \\
+\beta_{3} \text { Work }_{d} \text { isat }+\beta_{4} \text { Migration }+\beta_{5} \text { Age }+\beta_{6} \text { Familysize }+ \\
\beta_{7} \text { Gender }+\beta_{8} \text { Marital }+\beta_{9} \text { FamilySize }+\varepsilon
\end{array}
$$

Where all variables are as defined and presented in table 4.

The result of the probit analysis shows that out of the proposed nine variables six of them are found to statistically significant to determine the workers probability of the intention to leave their company (as a proxy for high turnover). Relationship with supervisor, satisfaction with job, working environment and salary are the most important factors determining the probability of workers intention to leave textile manufacturing industry. However, the result presented that among the proposed variables, age, marital status, and migration are insignificant.

As explained earlier Relation with a Supervisor the marginal coefficient indicates that a change in the supervisor relation from bad to good has a marginal effect of about $10.7 \%$ less likely to leave the company. Previous studies have shown that this variable not only affects intentions to leave (Gerstner and Day, 1997), but also affects performance Liden et al. (2006), and organizational commitment Mutsuddi (2016). Although, the data collected revealed that there is generally a good relationship between supervisor and operators, the information through key informants showed that most of the time there is a rough relation between the supervisors and the board members or top managers.

Job dissatisfaction the marginal coefficient indicates that a change swift from being satisfied to being dissatisfied has increases about $23 \%$ probability of employees' intention to leave the company. The finding is in line with the findings of DeConinck (2009). In contrast, others have reported nonsignificant relationships between satisfaction and turnover intentions Harris and Cameron (2005) and Kacmar et al. (1999). In this study, work environment coefficient indicates that a change in the satisfaction from being neutral to being dissatisfied has a marginal effect of about $12.1 \%$ on intention to leave, meaning that employees are $12.1 \%$ more likely to leave the company if dissatisfied.

Workers impression on the monthly salary indicates a change from being neutral to being dissatisfied has a marginal effect of about $10.3 \%$ increase in the probability of the intention to leave. It means, citrus paribus, employees are $10.3 \%$ more likely to leave the company. This finding is well supported by the findings of Barrett and Baumann-Pauly (2019) at Hawassa Industrial Parks also that indicated the firms pay low wages. A gender the result shows that females are more likely to leave the job than males, which is significant at $5 \%$ level. As explained in the descriptive analysis the result from KII shows that females have more difficulty to cope up with the working environment and difficulty in the nature of the job. On the other hand, family size of the employees is negatively significant at $5 \%$ as expected. The marginal coefficient indicates a one person increase in the family will decrease the intention to leave by $3.1 \%$, other factors constant.

Table 5: The marginal effect after Probit Estimation $\mathrm{y}=\mathrm{Pr}$ (intention to leave) (predict) $=0.88898582$

\section{Conclusions and Policy Recommendations}

A total sample of 142 workers with different capacities were randomly selected from the companies and interviewed using a standard questionnaire to draw inference for the study. The data was collected using tablets deploying the CSpro software. Statistical tools and the Probit econometric model were applied for the data analysis. Despite the current high staff turnover and subsequent impacts on cost and productivity, the managers (owners) of the companies do not seem to make sufficient effort to reduce the problem. As sorts of motivation, companies provide incentives such as transport service, health security, holiday gift and sometimes subsidized sales of food. However, respondents feel these are trivial to retain workers in the company. In conclusion, the problem of high turnover is wearisome, and the major causal factors are dissatisfaction of the workers with their job, working environment and salary that implicitly means forced or involuntary turnover, and they do really not adore leaving their company or job. This is evidenced with the fact that the companies do not seem seriously concerned about the matter, which might be because of the available cheap and abundant labor in the market easily to replace. High turnover is painful to the workers and in any ways adversely affect the companies' profitability. The implication for the government to plan for job creation and reduce unemployment problem will be questionable. The following recommendations are forwarded based on the study results:

- The companies should revisit and improve their management styles. These include concern of humanity and creating sense of belongingness through improving friendly relationship all along the organizational structure - between owners and managers, managers, and supervisors and further between supervisors - operators.

- Harmonizing wages rates with workload/stress and provision of safety protection are crucial to reduce high turnover for sustainable development of the industry.

- Women workers need special attention to create favorable working conditions such as suitable work types, provision of health care facilities and exempting night shifts are area of improvement to encourage them and retain in the companies.

- It is suggested to establish workers' union to have strong collective voice to protect their rights and be able to negotiate with the companies to improve the workers' needs and satisfaction for mutual benefits.

- The companies should periodically undertake studies in relation to employee turnover and based on the studies should prepare mitigation strategies.

- Further investigation is encouraged to comprehend details of the cause of the problems, particularly from the demand side (the company owners) for policy actions.

\section{Competing Interests}

Author declare no competing interests. 


\section{References}

Alase, G. and Akinbo, T. (2021). Employee motivation and job performance: Empirical evidence from nigeria, Applied Journal of Economics, Management and Social Sciences 2(2): 16-23. URL: https://nokspublishing.com/index.php/AJMSS/article/view/20

Allen, D. G., Shore, L. M. and Griffeth, R. W. (2003). The role of perceived organizational support and supportive human resource practices in the turnover process, Journal of Management 29(1): 99-118.

Alshmeri, M.and Shahwan-Akl, L. and Maude, P. (2017). Herzberg's two-factor theory, Life Science Journal 14(5): 1216.

Central-Statistical-Agency (2014). Statistical Report on the 2013 National Labor Force Survey, Statistical Bulletin.

Chew, Y. and Wong, S. (2008). Effects of career mentoring experience and perceived organizational support on employee commitment and intentions to leave: a study among hotel workers in malaysia, International Journal of Management 25(4): 692-700.

Cochran, W. G. (1963). Sampling techniques, Wiley.

Cohen, A. (2003). Multiple commitments in the workplace: An integrative approach, Lawrence Erlbaum.

Cohen-Charash, Y. and Spector, P. E. (2001). The role of justice in organizations: a meta-analysis, Organizational Behavior \& Human Decision Processes 86(1): 278-321.

Cole, M. and Bruch, H. (2006). Organizational identity strength, identification, and commitment and their relationships to turnover intention: does organizational hierarchy matter?, Journal of Organizational Behavior 27(5): 585605.

De-Cuyper, N., Notelaers, G. and De-Witte, H. (2009). Transitioning between temporary and permanent employment: a two-wave study on the entrapment, the stepping stone and the selection hypothesis, Journal of Applied Psychology 82(1): 67-88.

DeConinck, J. (2009). The effect of leader-member exchange on turnover among retail buyers, Journal of Business Research 62(11): 1081-1086.

ECarsten, J. M. and Spector, P. E. (1987). Unemployment, job satisfaction, and employee turnover: a meta analytic test of the muchinsky model, Journal of Applied Psychology 72(3): 374-3.

Eisenberger, R., Huntington, R., Hutchison, S. and Sowa, D. (1986). Perceived organizational support, Journal of Applied Psychology 71(3): 500-507.

Erdogan, B., Talya, N. B., Donald, M. and Layla, R. M. (2012). Whistle while you work: A review of the life satisfaction literature, Journal of Management 38(4): 1038-1083.

FDRE (2016). National employment policy and strategy, FDRE.

Ferreira, L. C. and Almeida, C. B. (2015). Employee turnover and organizational performance: a study of the brazilian retail sector, Brazilian Business Review 12(4): 27-56.

Gamble, J. and Huang, Q. (2008). Organizational commitment of chinese employees in foreign-invested firms, International Journal of Human Resource Management 19(5): 896-915.

Gerstner, C. R. and Day, D. V. (1997). Meta-analytic review of leader-member exchange theory: Correlates and construct issues, Journal of Applied Psychology 82(6): 827-844.

Ghoddousi, P., Bahrami, N., Chileshe, N. and Hosseini, M. R. (2014). Mapping site-based construction workers' motivation: Expectancy theory approach, Construction Economics and Building 14(1): 60-77.

Graen, G. B., Liden, R. and Hoel, W. (1982). Role of leadership in the employee withdrawal process, Journal of Applied Psychology 67(6): 868-872.

Graen, G. B. and Uhl-Bien, M. (1995). Relationship-based approach to leadership: development of leader-member ex- change ( $\operatorname{lmx}$ ) theory of leadership over 25 years: applying a multi-level multi-domain perspective, The Leadership Quarterly 6(2): 219-247.

Gujarati, D. (2004). Basic Econometrics 4th ed., McGraw-Hill Companies.

Harrie, G. (2002). Career development interventions in the 21st century, 5th Edition, Merrill Prentice Hall Publication.

Harris, G. E. and Cameron, J. E. (2005). Multiple dimensions of organizational identification and commitment as predictors of turnover intentions and psychological well-being, Canadian Journal of Behavioral Science 37: 159-169.

Hayibor, S. and Collins, C. (2016). Motivators of mobilization, Motivators of mobilization 139(2): 351-374.

Hom, P. and Griffeth, R. (1995). Employee Turnover, SouthWestern, Cincinnati.

Ilies, R., Nahrgang, J. D. and Morgeson, F. P. (2007). Leadermember exchange and citizenship behaviors: A metaanalysis, Journal of Applied Psychology 92(1): 269-277.

International-Labor-Organization (2019). skills for trade and economic diversification in Ethiopia, A background paper for drafting of sector skills strategy for the garment sector in Ethiopia.

Kacmar, K. M., Carlson, D. S. and Brymer, R. A. (1999). Antecedents and consequences of organizational commitment: a comparison of two scales, Educational and Psychological Measurement 59(6): 976-994.

Karatepe, O. M. (2012). The effects of coworker and perceived organizational support on hotel employee outcomes: the mediating role of job embeddedness, Journal of Hospitality and Tourism Research 36(4): 495-516.

Kwon, K., Bae, J. and Lawler, J. (2010). High commitment $\mathrm{hr}$ practices and top performers: Impacts on organizational commitment, Management International Review 50(1): 57-80.

Liden, R. C., Erdogan, B., Wayne, S. J. and Sparrowe, R. T. (2006). Leader-member exchange, differentiation, and task interdependence: implications for individual and group performance, Journal of Organizational Behavior 27(6): 723-746.

Martin, P. (2005). Managing employees turnover (9th Edition), Sultan Chand \& Sons Jersey Press.

Matei, M. and Abrudan, M. (2016). Adapting Herzberg's twofactor theory to the cultural context of Romania, Procedia-Social and Behavioral Sciences, 221 (13th International Symposium in Management: Management During and After the Economic Crisis).

Mauno, S., De-Cuyper, N., Kinnunen, U., Ruokolainen, M., Rantanen, J. and Mäkikangas, A. (2015). The prospective effects of work-family conflict and enrichment on job exhaustion and turnover intentions: comparing long-term temporary vs permanent workers accross wave, Work and Stress 29(1): 75-94.

Menon, A., David, E., Das, D. and Mohan, R. (2018). Modeling the determinants of turnover intentions: a bayesian approach, Evidence-based HRM: a Global Forum for Empirical Scholarship 6(1): 2-24.

Morrow, P. C., Suzuki, Y., Crum, M. R., Ruben, R. and Pautsch, G. (2005). The role of leader-member exchange in high turnover work environments, Journal of Managerial Psychology 2(8): 681-694.

Mutsuddi, I. (2016). Employee retention and engagement practices in the healthcare sector: A study on medica superspecialty hospital, kolkata, Delhi Business Review 17(1): 6578.

Noko, E. and Nwuzor, J. (2021). Employee and organisational performance: Employees perception of intrinsic and extrinsic rewards system., Applied Journal of Economics, Management and Social Sciences 2(1): 26-32.

URL: https://nokspublishing.com/index.php/AJMSS/article/view/5 Oregon, L. (2004). Staff training and development.(1st Edition), 
Pearson Publishers.

Rode, J. C., Rehg, M. T., Near, J. P. and Underhill, J. R. (2007). The effect of work/family conflict on intention to quit: the mediating roles of job and life satisfaction, American Journal of Dance Therapy 2(2): 65-82.

Van-Breukelen, W., Van-der Vlist, R. and Steensma, H. (2004). Voluntary employee turnover: Combining variables from the turnover literature with the theory of planned behavior, Journal of Organizational Behavior 25(7): 893-915.

Vecchio, R. P. (1985). Predicting employee turnover from leader-member exchange: a failure to replicate, Academy of Management Journal 28(2): 478-485.

Vroom, V. H. and Deci, E. L. (1983). Management and motivation, Penguin Group. 